\title{
Adaptive reuse of commercial and public buildings in Wroclaw Old Town in Poland. The occupant's safety and comfort versus preservation of authenticity of monumental buildings
}

\author{
Krystyna Kirschke \\ krystyna.kirschke@pwr.edu.pl
}

\section{Paweł Kirschke}

pawel.kirschke@pwr.edu.pl

\section{Elżbieta Komarzyńska-Świeściak elzbieta.komarzynska-swiesciak@pwr.edu.pl}

Department of Civil Service Building Architecture and Basics of Design, Faculty of Architecture of Wroclaw University of Science \& Technology

\begin{abstract}
There are more than a hundred historic public buildings in the centre of Wrocław, adapted to fulfill modern commercial function. Against the background of today's cosmopolitan shopping centers and office buildings, these buildings are distinguished by stylish architecture, maintained in eclectic, Art Nouveau or modernist forms. In the process of renewal of such monumental buildings, there is a need to reconcile the requirement for maximum protection of the historic material with safety and comfort of use. The multi-disciplinary construction design constituting the basis for the adaptive reuse of the heritage building must be preceded by conservation research and concept designs simulating possible program options. This allows linking the assessment of the value of the architecture with a choice of the matching function corresponding to the location and historic structure of the building. The further multi-disciplinary design process and implementation of such a project should be based on the Research by Design scheme. This allows for control of the implementation of the project and to rationalize the necessary upgrade of the facility with the application of such space and technical solutions that limit the destruction of its historic substance. The paper presents conclusions from several adaptive reuse projects carried out in such a way, in which it was possible to create high-class department stores, banks, hotels or prestigious offices inside the heritage buildings. The essence of these developments was to preserve the authenticity of the monumental building, while providing the necessary infrastructure, plant rooms and equipment guaranteeing safety and comfort of use.
\end{abstract}

Keywords: adaptive reuse, commercial buildings, heritage building preservation, Research by Design, sustainable development, Wrocław

\section{Acknowledgments}

We thank architects from following architectural practices: grupa 33_03, Biuro Projektów i Ekspertyz ARCHIKON, MTA Tomasz Marhall and Maćków Pracownia Projektowa for providing Building Permit Documentation of some of the architectural projects analysed in the article that greatly assisted the research. 


\section{Introduction}

At the beginning of the $21^{\text {st }}$ century, a development boom took place in Wrocław, which resulted in the completion of four hundred commercial buildings, including over one hundred located in revitalized historic buildings, mainly those built at the turn of the $19^{\text {th }}$ and $20^{\text {th }}$ century [1]. The largest concentration of this type of facility took place in the area of the historic centre: in the Old Town and the Przedmieście Świdnickie suburb, where modern department stores, banks, hotels, restaurants and entertainment facilities, as well as prestigious offices, were located in the refurbished monumental buildings. Against the background of today's cosmopolitan commercial buildings, these facilities are characterized by stylish architecture maintained in forms: eclectic, Art Nouveau or modernist. They are special features of the most important streets and squares, and their commercial content essentially contributes to the transformation of the historic centre of Wrocław into the metropolitan business centre and a tourist destination [2]. The leading role in the success of these developments was played by the architectural and conservation strategies applied during the design process, which allowed to preserve the authenticity of the architectural monument and to display its esthetic properties, while ensuring safety and usability, which also involved the introduction of necessary infrastructure, plant rooms and equipment.

It is well known that historic buildings of all types, including centuries-old Gothic, Renaissance or Baroque buildings can be used for modern commercial purpose, however, the cost of providing standard commercial areas is astronomical (due to the scope of refurbishment and adaptation works). Therefore, in Wrocław, the buildings created in the imperial times of the Deutsches Kaiserreich (in 1890-1914) and the modernist decade of the Weimarer Republik (in the years 1925-1933) are most often subjected to refurbishment for modern commercial use. These were two periods of splendor in Wrocław (then Breslau), during which the romantic Old Town was transformed into a city, comprising of over 300 modern public buildings and 1,000 residential and commercial buildings. Of these, 60 department stores, 15 banks, 20 office buildings, 15 hotels and 300 multifunctional facilities have survived to this day [3]. All these buildings were built in accordance with the strict regulations of the construction law in force at that time. Their structures ensure safety and comfort for users, and fire-resistant constructions made it possible for them to survive fires during World War II. Also today, these facilities meet most of the applicable technical requirements. This applies to the load-bearing capacity of the main structure and durability of facades, layout of the most important areas, including their height and provision of daylight, as well as the layout of horizontal and vertical escape routes. Therefore, relatively easily and without large losses in a historic substance, they can be subjected to processes of adaptive reuse to modern functions. Over the last twenty years several dozen of them have undergone professional conservation and extension, thanks to which they function today as modern commercial facilities. Their contemporary use refer to the time of the original function, but sometimes a drastic change in the way of use takes place. Mostly, multifunctional buildings are being built, containing commercial, banking, catering or entertainment facilities on the lower floors, and offices, hotel rooms or apartments on the upper floors. The largest groups of complex buildings are commercial buildings, hotels and class A or B office buildings. The subject of this article is the review of refurbishment of historic commercial buildings including adaptation to modern commercial function.

\section{Aims and methods}

Nineteen modern developments involving the adaptive reuse of commercial facilities in the Old Town in Wrocław were selected for research. The principal scientific method adopted for the purposes of the planned research was comparative analysis. The authors' own professional experience in design and supervision of over fifty similar developments was used as the basic material for analysis. In order to thoroughly examine the remaining examples, queries, field studies, studies of the design, applicable legal acts and planning documents, as well as consultations with conservation officers, designers, developers, users of the buildings in question were carried out [4-10].

The paper presents the conclusions from the above-described projects, during which high-class department stores, banks, hotels or prestigious offices were created in heritage buildings. The essence of these developments was to preserve the authenticity of the building and to display its features, while providing the necessary infrastructure and plant rooms as well as equipment guaranteeing safety and comfort of use. The aim of 
the research was to identify and describe the design strategies encountered in the processes of conservation of commercial facilities and to indicate recommendations for the optimal implementation of this type of construction projects in line with the principles of the sustainable development.

\section{Sustainable design strategies for the restoration of historic commercial buildings. Case study presentation}

In the process of conservation of heritage buildings, especially those adapted for prestigious public facilities, there is always a need to reconcile two priorities: conservation and technology. According to them, maximum protection and exposure of a valuable historical substance should be sought, as well as all aspects of the safety of large groups of users should be strictly guaranteed. The implementation of these goals takes place through a design process based on a scheme referred to as Research by Design [11, 12]. It involves survey of building and creating a detailed conservation program already in the pre-design stage. At the same time, an optimal functional program that meets specific social needs and ensures a profitable venture is being pursued. The multi-disciplinary construction design, which is the basis for the project, must be preceded by optional architectural concept designs based on conservation, technology and marketing research. These concept designs are developed to generate and optimize the final space planning appropriate to the rank of the monument and its location - which must also correspond with the provisions of the current Local Spatial Development Master Plan.

It allows for professional assessment of the value of architecture and undertaking correct decisions in the construction design regarding the scope of the reconstruction of its building structure, methods of conservation of historic elements in connection with the selection of the appropriate program for all rooms. It is necessary to meet comfort requirements and fire safety. All in all, it allows rationalizing the necessary changes in the structure of the building, with the use of technology that limits the destruction of its historic substance. The implementation of such a programmed undertaking must be based on extremely detailed and technological designs. It is necessary to constantly monitor the course of the project, which is carried out as part of the architect's supervision. Often during the implementation, design decisions and changes in documentation are re-evaluated [13]. This is due to the fact that survey of the monument is still taking place on the construction site, and every discovery must be analysed and, if necessary, followed up by the detail design. In each of the described cases, thanks to the work of scientists and multi-disciplinary design teams and professional contractors, it was possible to create comfortable utility spaces well-matched to the type and size of the heritage building, avoiding irreversible interference in its structure [13]. It was connected with the maximum protection of stylish facades, representative interiors and old structures. All-important historic elements were renovated and maintained. The leading role was played by architectural decisions combining the principles of conservation programs, ensuring fire safety and compliance with regulations, as well as broadly understood security.

Owing to such coordination, it was possible to create the best conditions for the customer and an "ideal" working environment. At the same time, it gave users a sense of ennoblement resulting from the fact that they are staying in a building with dazzling architecture. Achieving these effects usually lead to enormous technical problems. This involved the necessity to rebuild the foundations and strengthen the structure, revise the escape routes and build new elements of vertical transport, as well as implant the parking lots in the buildings. Significant changes were also caused by the desire to optimize the conditions of use, including improvement of heat balance and introduction of environment friendly solutions. This generated the need to provide a variety of services and related ducts and large plant rooms. These devices had to be placed in existing historic basements, attics or on roofs, which triggered many conservation problems. All in all, it required all stages of the development to set priorities and make critical technical decisions that would reconcile (often contradictory) conservation and construction plans. They were not easy and sometimes they had to be based on compromises. 


\section{Assessing the adaptability of different types of public buildings. Analysis and discussion}

\section{Adaptability of historic commercial buildings}

As already mentioned, conservation and extension projects related to the adaptive reuse of historic buildings to modern functions in Wrocław are most often taking place in old department stores (Kaufahaus, Warenhaus) and multi-purpose department stores such as Geschäftshaus, offices and banks, as well as hotels, and both cultures established at the turn of the $19^{\text {th }}$ and $20^{\text {th }}$ century. Space planning of these historic buildings, the composition of their façades and structure are a derivative of their original function. For example, in the department stores, open space floors based on multi-storey skeletal building structures were designed, and the façades were shaped to provide the maximum amount of daylight in the interiors and to create large exhibition spaces. Hotels, offices and banks at the turn of the century received monumental forms referring to palace architecture, with pompous lobbies and prestigious rooms in the commercial sections, as well as corridor layouts in case of residential or office sections $[14,15]$. The structure of these buildings was based on massive transverse and external walls. The windows were relatively small. All façades of public buildings had a durable stone or ceramic face of the façades, which in the Wilhelmine period was enriched with a rich stylish decoration (German styles: Eklektizismus, Jugendstil, Neobarock, Neorenaissance) The buildings from the Modernism era looked different, their structure was shaped primarily in terms of maximum simplicity and functionality of the building (styles Neuen Sachtlichkeit, Moderne). The exceptions were prestigious offices and commercial buildings for which expressionist forms or a luxurious version of modernism were used - Art Déco [3]. Not only the façades, but also the crowning of the buildings evolved from turn of the century's dominating rich compositions consisting of towers, peaks and pitched roofs (or mono-pitched roofs hiding spacious attics) to flat roofs used from the 1920s (Fig. 1-2). All in all, all these buildings dazzled with their composition, the technical quality of the built elements and the artistic detail. Their rich forms in the case of offices and banks were to show the majesty of power and in the case of commercial buildings and hotels magnetize the public. The interiors were usually well suited for fulfilling the coordinated functions. They were spacious and well-lit, although often attention was not paid to their correct location in relation to the sun, which caused excessive insolation or overheating of rooms.

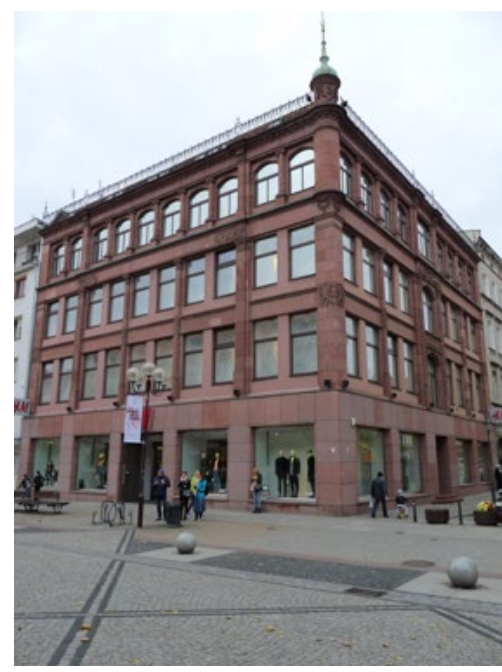

Fig. 1. Hennes \& Mauritz department store (H\&M) refurbished in 1997-2004 in accordance with Studio EL (photo by P. Kirschke).

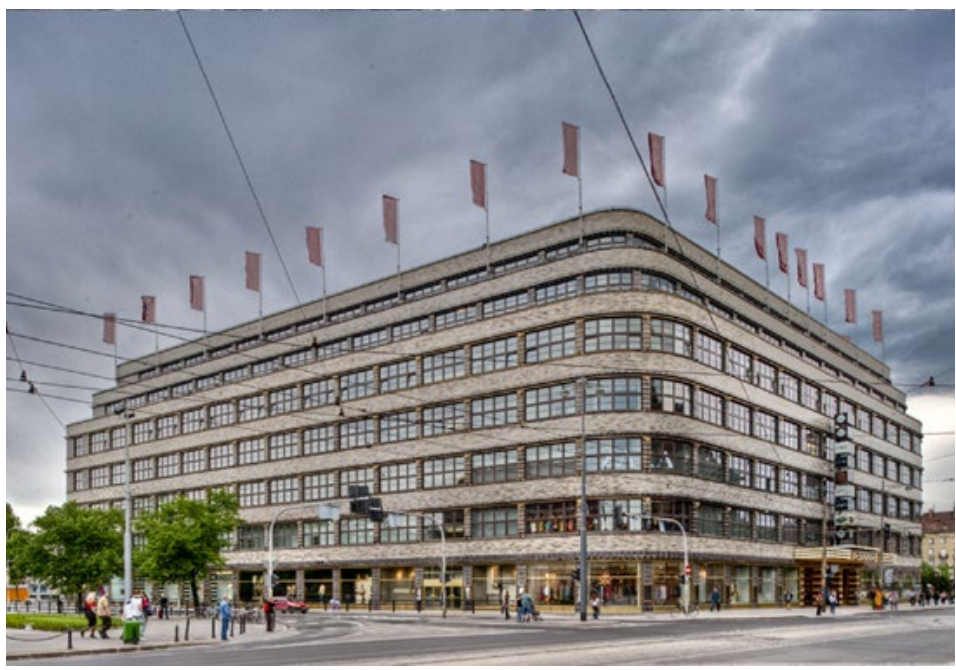

Fig. 2. Renoma Department Store refurbished and extensioned in 2005-2009 in accordance with the design of Pracownia Projektowa Maćków (photo by J. Sokołowski). 
The buildings contained also some dubious solutions, affecting today's problems with their adaptation to modern functions. The disadvantages include irrationally large entry and communication spaces. Open halls and stairwells were exposed to smoke during a fire. In the entrance areas there were usually massive doors and complicated vestibules that hindered access to the building. The problem was also the loss of heat caused by a high coefficient of heat transfer through building partitions and the loss of energy through roof skylights and single glazed windows. The wooden, iron and steel structures of older buildings had a low load-bearing capacity and unsatisfactory fire resistance. Basically it improved after wide spread use facing to steel and reinforced concrete structures (Fig. 3-4). As far as infrastructure is concerned, in the last decade of the $19^{\text {th }}$ century buildings were fitted with electrical, telecommunications and plumbing systems as well as relatively efficient central heating systems (including air heating ducts). From the mid-1920s, fire hydrants and fire tanks were introduced. Also, the provision of separate escape staircases was strictly required. The mechanical ventilation and air conditioning were still missing, which to some degree was compensated by the perfectly implemented natural ventilation (the airflow was infiltrated). All the buildings were fitted with electric elevators. Escalators appeared in the late 1920s, but they were rare. In commercial buildings, entrance to the building was to be as easy as possible for public access, which made them also well accessible to the disabled. However, the same can not be said about offices or banks where, due to the need for grandness, raised ground floors and pompous stairs at the entrances were designed, which created terrible architectural barriers.

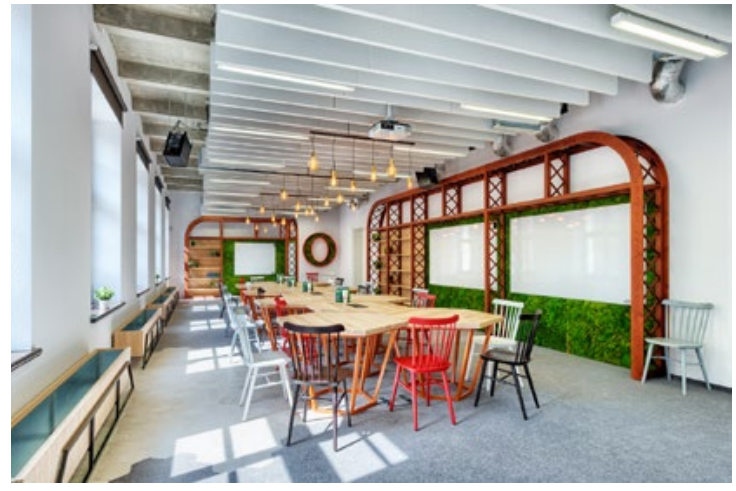

Fig. 3. Meeting room inside Hieronimus I Office Building refurbished and extensioned in 2015 in accordance with the design by Grupa 33_03, interior design by mode:linaTM (photo by mode:linaTM).

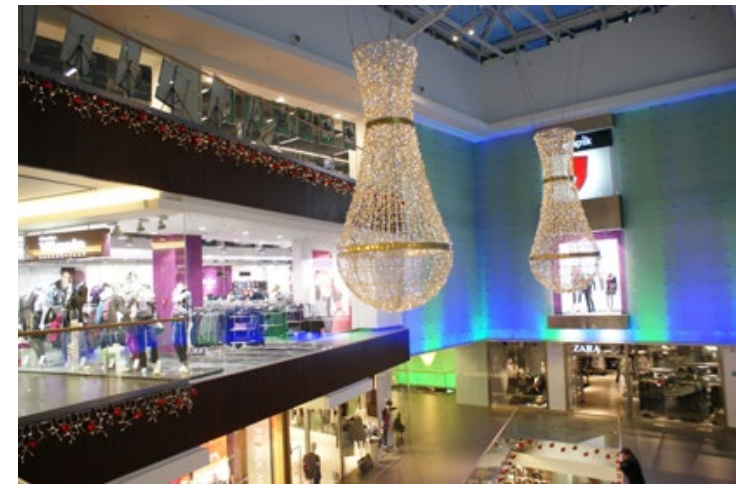

Fig. 4. The atrium of Renoma Department Store refurbished and extensioned in 2005-2009 in accordance with the design of Pracownia Projektowa Maćków (photo by A. Krupa).

\section{Adaptive re-use for commercial purpose}

The structures of historic department stores are most suitable for adaptive reuse to modern commercial functions. They were fitted with repeatable open floor plans - which are also a best option for contemporary commercial buildings for high-profile companies. They have skeletal, post-beam or frame structure with large spans up to $12 \mathrm{~m}$, stiffened by staircases, lift shafts and gable walls, which also serve as effective fire walls. Finally, these buildings are elegant, fitted with huge windows, richly decorated facades with a ceramic face or made of Silesian stone: sandstone or travertine. The listed values and excellent locations of these buildings on the main streets of the centre of Wrocław also today make them suitable for commercial, banking, catering and office functions. Examples of such refurbished and efficient historic structures are: Hennes \& Mauritz department store (H\&M) at Świdnicka 7 Street (former Geschäftshaus Paul Schottländer, built in 1897, arch. Karl Grosser, in 1997-2004 refurbished in accordance with Studio EL design); Feniks Department Store at Rynek 31/32 (former Warenhaus Gebrüder Barasch built in 1904, arch. Georg Schneider, in 1997-2015 a several-stage refurbishment took place in accordance with the design of Kirschke Pracownia Projektowa [5]); the Renoma Department Store at Świdnicka 40 Street (former Warenhaus Wertheim erected in 1929-1930, arch. Hermann Dernburg, in 2005-2009 refurbished and expanded in accordance with the design of Pracownia Projektowa 
Maćków [4]); Department Store GRE 1, EMPiK, at Rynek 50 (former Geschäftshaus Hünert, built in 1904, designed by Leo Schlesinger \& Hermann Benedickt, refurbished in 2001 in accordance with Kapitońscy design and in 2012 in accordance with the design of Kirschke Pracownia Projektowa [6]); Kameleon Department Store at Oławska 7/8 Street and Szewska 6/7 Street (formerly Kaufhaus Rudolf Petersdorff, built in 1928, arch. Erich Mendelsohn, refurbished in 2007 in accordance with the design of KMA Kabarowski Misiura Architekci and in 2015 in accordance with the design of Kirschke Pracownia Projektowa).

Architectural and conservation issues related to the adaptive reuse of these buildings have been already described by the authors of this article [1,3,16-19]. Here, let's concentrate on program and technical issues as well as those related to ensuring safety and comfort of use. Due to the unique architecture of these buildings and the individual functional programs selected for them, the scope of construction and adaptation works was different each time. One can, however, try to draw conclusions and generalizations about the methods and effects of these conservations. However, one must remember that all decisions were made taking into account the fact that these are heritage buildings. Therefore, in cases when it was necessary due to the desire to preserve the historical elements of the building, or due to the adopted construction process, numerous non-standard solutions and derogations from provisions were used to apply relevant standards in a slightly different than usual way [20]. This included, for example, omitting insulation of external facade due to rich architectural details, the lack of daylight in some utility rooms, and applying nonstandard solutions allowing the separation of fire zones and ensuring safe evacuation.

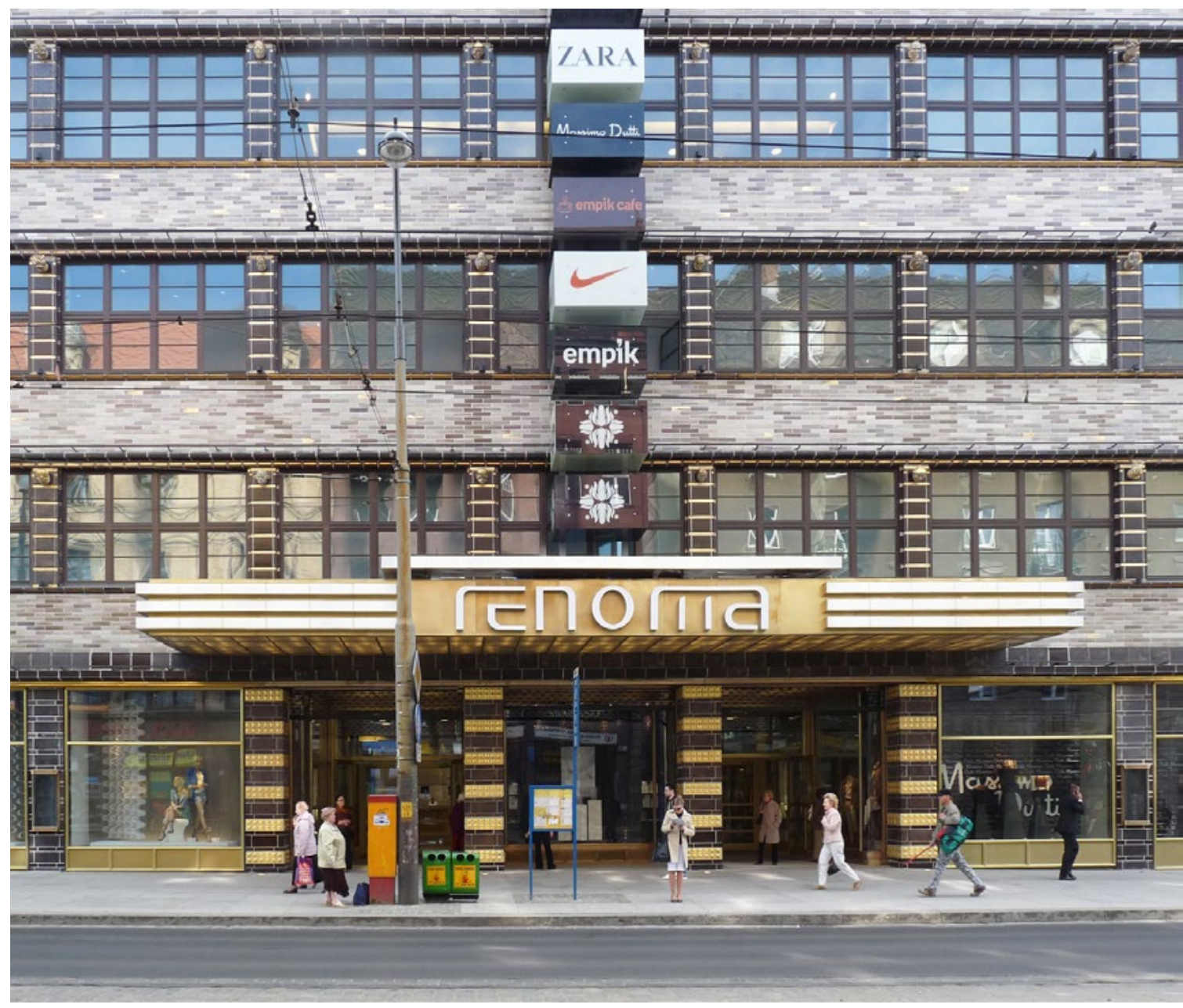

Fig. 5. The main entrance to Renoma Department Store, refurbished and extensioned in 2005-2009 in accordance with the design of Pracownia Projektowa Maćków (photo by P. Kirschke). 
The first factor in the process of refurbishment of historic commercial buildings were decisions on how to use them, which had to be matched to the historic structure of the building. The selection of this program was of critical importance due to the need to face the competition of several large shopping malls and shopping centers built on the outskirts of the historic centre of Wrocław. As demonstrated by the practice in the refurbished historic buildings, the Ground Floor and the Basements were housing sale of household and food products (including alcohol) as well as catering and banking services. In larger buildings, retail functions were also spread on the First, Second and Third Floors, but it was rarely successful. Various types of offices or apartments were located on upper floors, for which separate entrances and independent staircases had to be provided.

Due to the specifics of the main commercial function of the building, the space planning and fitting of all areas of the building, starting from entrances through all interiors, had to meet the technical requirements defined for ZLI Fire Zones [21], guaranteeing the safety and comfort of the "crowds" of customers. For example, in the entrances to retail facilities, the priority is high throughput and comfortable accessibility for customers, including people with disabilities. Architectural barriers are removed at all costs. The equalizing steps are eliminated by adjusting levels of the pavement and the Ground Floor or by providing gentle ramps in the entrance area. In order to increase the transparency and capacity of the entrance, the vestibules with complex systems are removed. In their place, light, glazed swing doors (modeled on the historic door system) or automatic sliding doors and efficient curtains (air or water) are provided (Fig. 5-8). In large buildings, where there is a danger of the so-called the chimney effect, two sets of doors and air curtains are fitted. In order to make it easier to keep the building clean, extensive doormat systems are installed in the main entrances (hard doormat, semihard and soft - a total of 7 steps required).

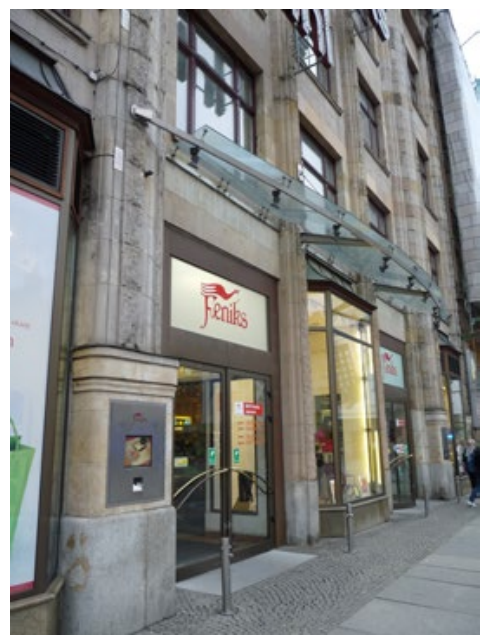

Fig. 6. The main entrance to Feniks Department Store refurbished in accordance with the design of Kirschke Pracownia Projektowa (photo by $\mathrm{P}$. Kirschke).

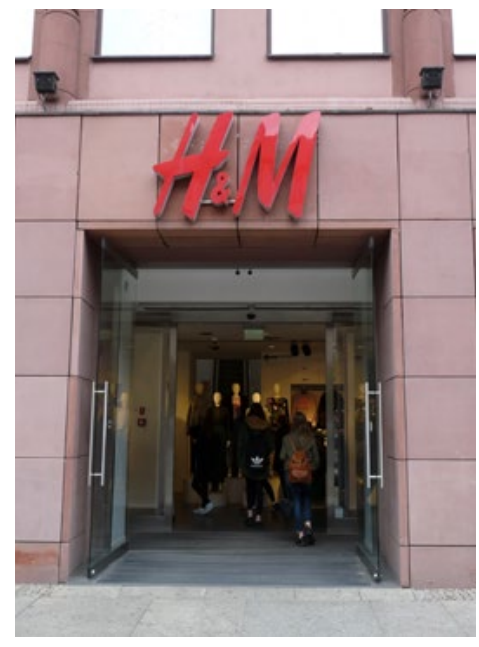

Fig. 7. The main entrance to Hennes \& Mauritz department store (H\&M) refurbished in 1997-2004 in accordance with Studio EL design (photo by P. Kirschke).

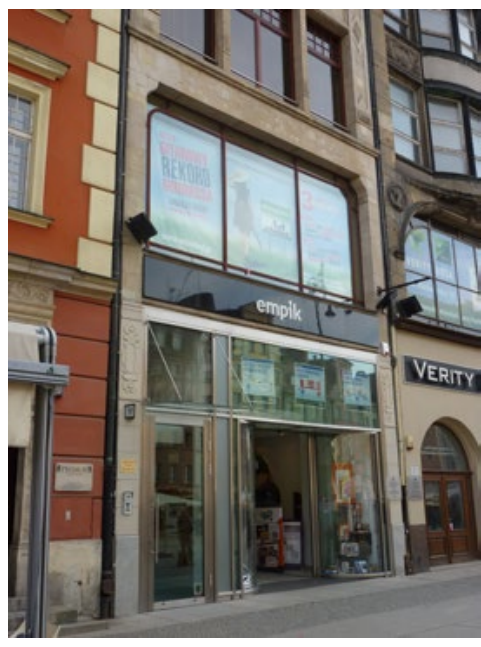

Fig. 8. The main entrance to EMPiK building refurbished in 2012 in accordance with Kirschke Pracownia Projektowa (photo by P. Kirschke).

All tenant premises must have attractive and wide entrances from outside or, in larger buildings, from the passage. It is important to secure the individual stores in terms of fire and theft protection, which is obtained by providing fire curtains to separate fire zones, roll-up gates and pedestrian security gates. It is crucial to provide adequate sales areas. The storeys of historic commercial buildings have suitable parameters for this. Their height is large, from 4.5 to $5.6 \mathrm{~m}$, which allows for easy fitting of any services and equipment, and masking them with suspended ceilings. The main elements of the historic structure: load-bearing walls, pillars and beams allow for the implantation of modern commercial functions and meet the current technical standards. It is different with floor slabs, where large groups of people move and where heavy and flammable goods are stored. These floor slabs do not have sufficient fire resistance and the required load capacity $\left(5 \mathrm{kN} / \mathrm{m}^{2}\right)$, which 
means that they usually have to be replaced. There are even more problems with premises placed in the basements, where obtaining a required height ( $3.0 \mathrm{~m}$ clear) usually means that the foundations have to be deepened.

According to current standards for retail buildings, it is assumed that they operate best without the access to daylight. In the case of historic buildings, this means that windows need to be covered or non-translucent, which is achieved by creating on the Ground Floor, and even on upper floors, shop windows fitted with back walls. To enable such rooms to function in accordance with Health and Safety Regulations, relevant permits have to be obtained. The Permit, issued by a competent Municipal Health Department in consultation with the Municipal Labor Inspector, can be obtained for a historic building without a problem, if we provide adequate room height, efficient mechanical ventilation and adequate artificial lighting [20, 21].

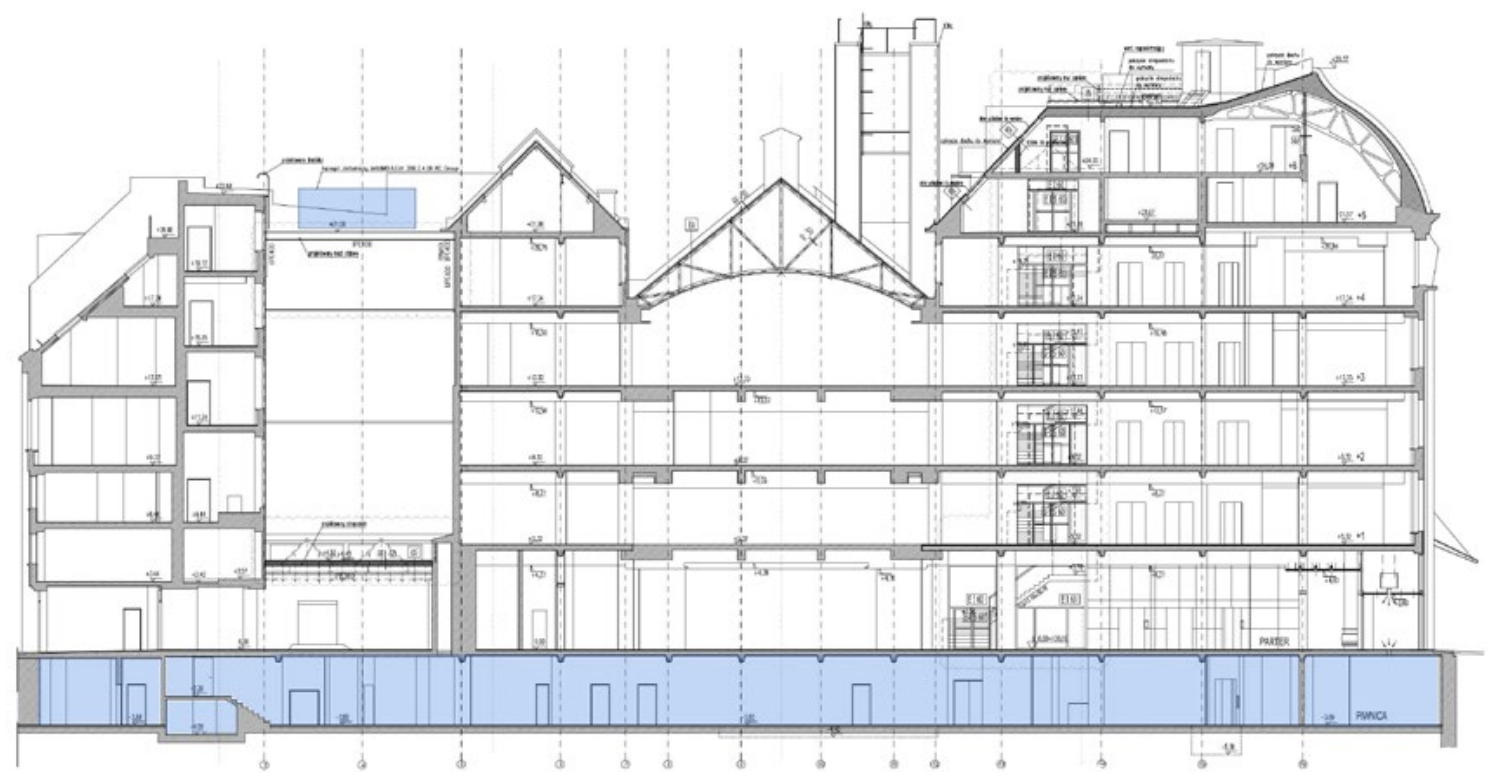

Fig. 9. Feniks Department Store refurbished in 1997-2015 - section drawing, plant rooms indicated with light blue color (by Kirschke Pracownia Projektowa).

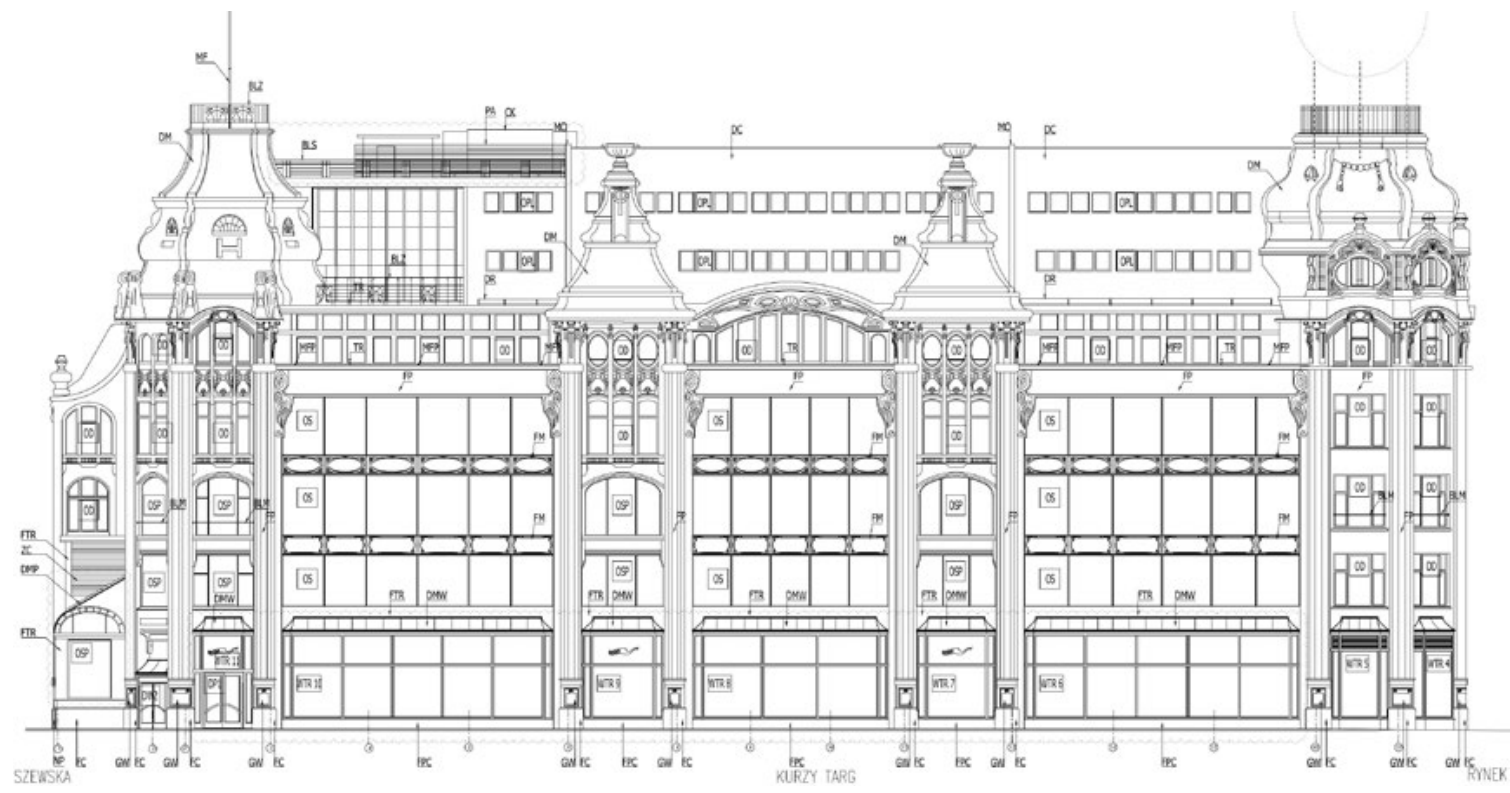

Fig. 10. Feniks Department Store refurbished in several stages in 1997-2015 - west elevation drawing (by Kirschke Pracownia Projektowa). 
Numerous derogations from provisions are made for fire escape routes: historic open staircases are adapted by installing smoke curtains and electronically controlled smoke extraction or aeration. For historic doors, alterations are approved to allow doors to be opened contrary to the direction of the escape routes.

The huge problem is the provision of delivery areas and parking, which are necessary for the operation of the facility. It is nearly technically impossible in the historic structure, that is why the parking garage is easiest to provide in the new wing, but this is what we can do only if the building is expanded.

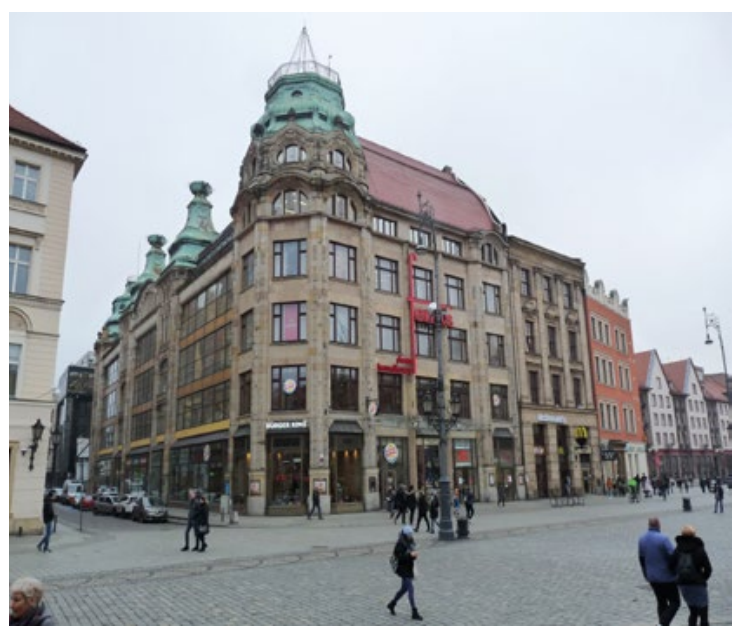

Fig. 11. Feniks Department Store refurbished in accordance with the design of Kirschke Pracownia Projektowa (1997-2015) - view from Świdnicka Street (photo by P. Kirschke).

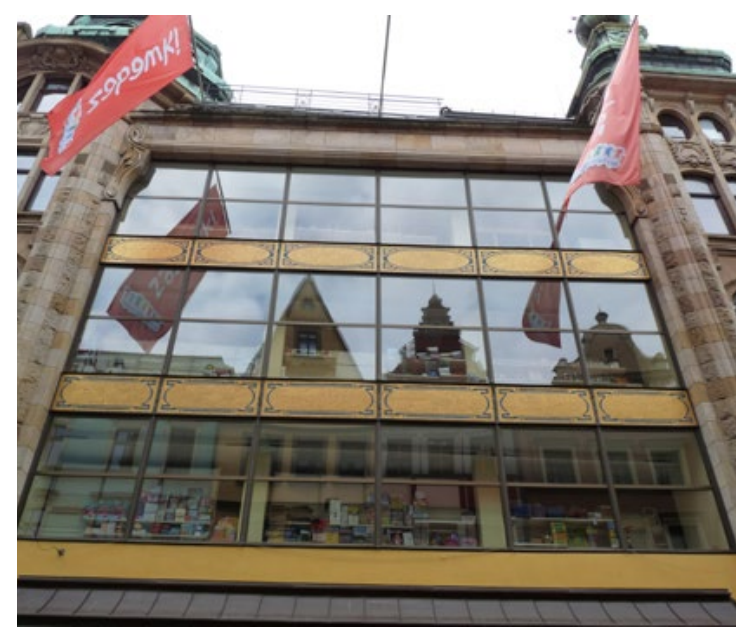

Fig. 12. Close-up look at the facade of Feniks Department Store building refurbished in accordance with the design of Kirschke Pracownia Projektowa (photo by P. Kirschke).

In Poland, historic buildings are exempt from the obligation to determine their energy performance in the form of energy certificates [20]. This provision was created in order to avoid a situation in which rigorous forcing of the improvement of the energy balance would cause a threat to the look and detail of the historic façades. However, in refurbished commercial buildings the aim is to reduce heat loss by improving the insulation coefficients of external walls, eliminating thermal bridges and places where condensation may occur in the walls. The rich building façades make it impossible to insulate walls from the outside, therefore insulation from the inside is used, which is advisable only in case of walls below the window sill. The improvement of the heat balance of the building is achieved by providing insulation of roofs, where the recommended $U \leq 0.25$ $\left[\mathrm{W} / \mathrm{m}^{2} \mathrm{~K}\right]$ heat transfer coefficient can be easily achieved. The replacement of glazing of windows, shopfronts and skylights (Lichthof - glass atrium) may also be carried out. Usually glass units with a heat transfer coefficient of $\mathrm{U} \leq 1.10\left[\mathrm{~W} / \mathrm{m}^{2} \mathrm{~K}\right]$ are provided, however, due to the common use of dry wall partition in shopfronts, a three-layer barrier effect with a heat transfer coefficient of approx. $U=0.50\left[\mathrm{~W} / \mathrm{m}^{2} \mathrm{~K}\right]$ is often achieved. The refurbishment of "Feniks" [5] (Fig. 9-12) and "Renoma" [4] (Fig. 13-17) department stores is the example of this option, where the wooden box windows were replaced with glass units which are a precise copy of the original window layout and proportions. In "Feniks" glazing of historic curtain walls was also replaced, where single glass panes were replaced with complex glass units fitted into the original steel structure (Fig. 12). Thanks to this, original details and gold-plated mosaics filling the space between the windows were preserved. The last element significantly improving the energy performance of the building is the elimination of so-called chimney effects (air curtains and fixed windows), and the replacement of natural ventilation with a mechanical ventilation, with heat gain system.

Large commercial buildings are fitted with water central heating system $\left(80 / 60^{\circ} \mathrm{C}\right)$ and process heat system, supplying mechanical ventilation and air curtains. For technical reasons, the Heating Substation and Main Plant Rooms are usually located in the Basement. This causes serious conservation problems, as exemplified by department stores at Rynek in Wrocław, where Plant Rooms were located in Gothic Basements, which could have been used much better as restaurants $[6,7]$. Therefore, if possible, it is best to locate Plant Rooms in new sections of the building. In the case of "Renoma" department store, huge Plant Rooms with a total floor area of 
A

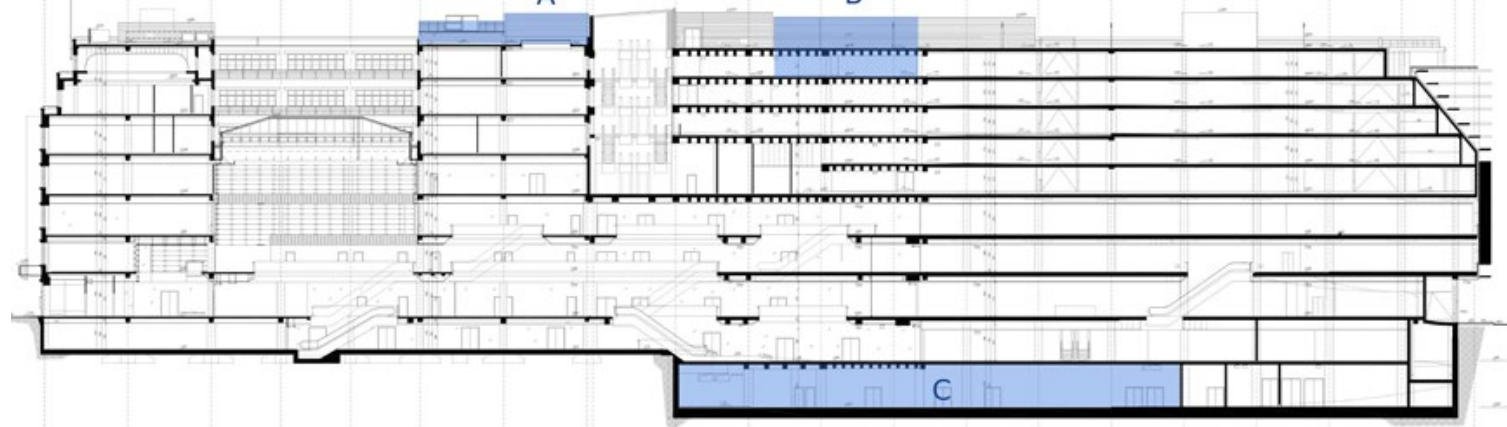

Fig. 13. Renoma Department Store - section drawing with plant rooms indicated with light blue color (by Pracownia Projektowa Maćków).

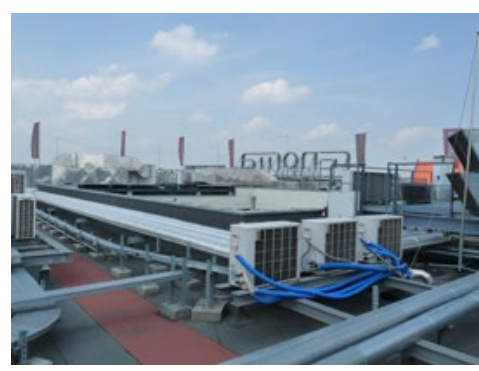

Fig. 14. Ventilation ducts (indicated with letter A in Fig. 13) on the roof of Renoma Department Store (photo by P. Kirschke).

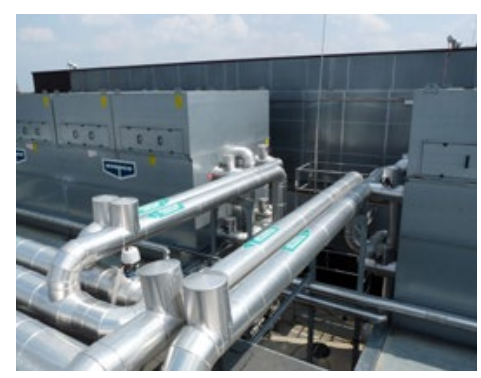

Fig. 15. Ventilation ducts (indicated with letter B in Fig. 13) on the roof of Renoma Department Store (photo by $P$. Kirschke).

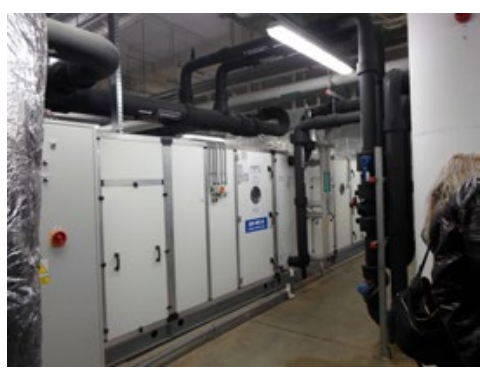

Fig. 16. The plant room (indicated with letter $C$ in Fig. 13) located in the basement of Renoma Department Store (photo by P. Kirschke).

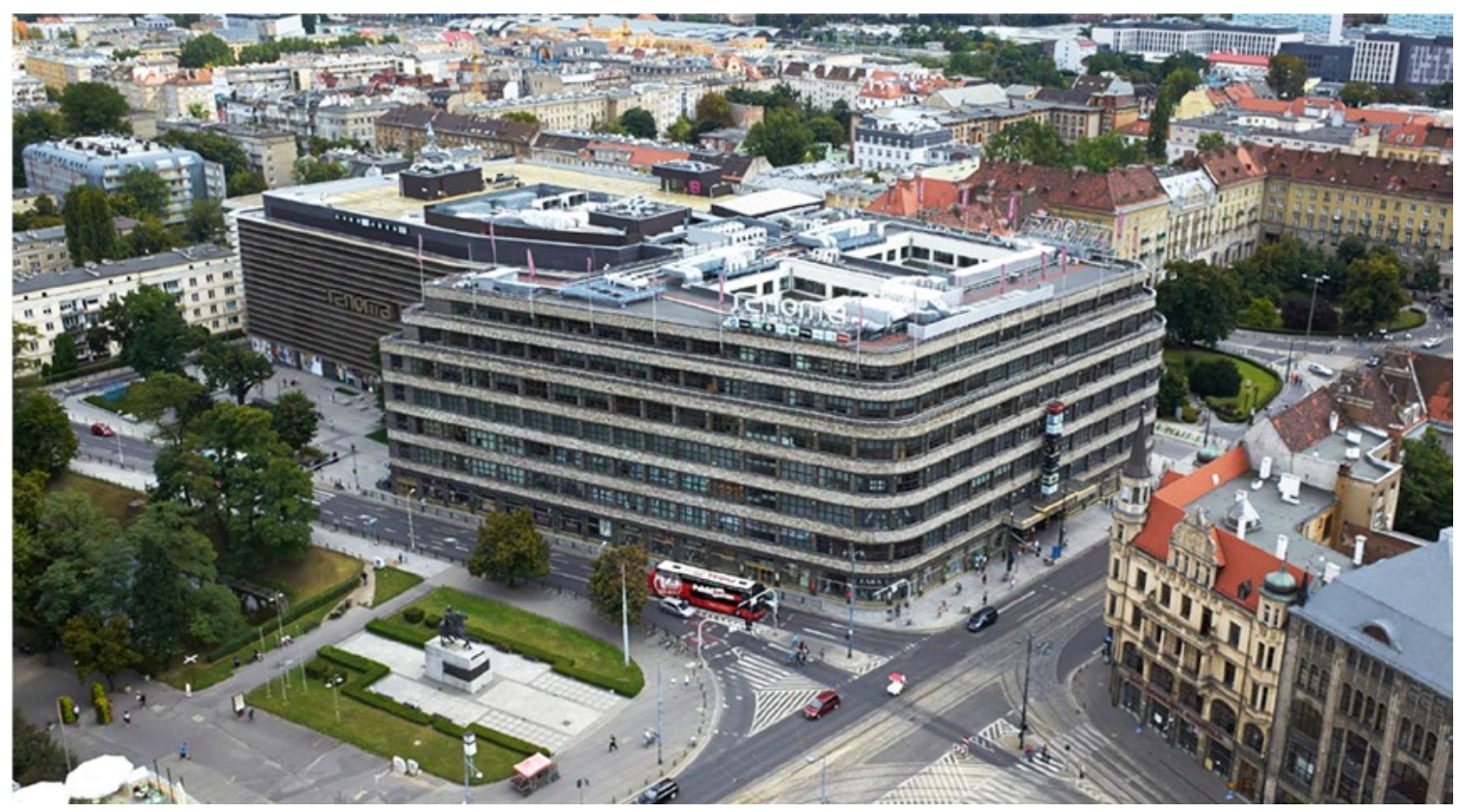

Fig. 17. The Renoma Department Store refurbished and extensioned in 2005-2009 - top view, ventilation ducts visible on the roof of the building (photo by Fotopolska). 
$4000 \mathrm{~m}^{2}$, including a Heating Substation with a capacity of $5.5 \mathrm{MW}$, were provided on level -2 of the new wing [4] (Fig. 13-17). A part of ventilation units, cooling towers and cooling units are located in attics or on roofs, which, however, creates the danger of distorting the building's outline. Therefore, the attempts are made to place them within the former light wells (in case of "Feniks" [5]) or in specially designed lower sections of the roof (in case of "Renoma" [4]). In both cases, it was also necessary to provide acoustic screens to reduce noise emissions, as the sound power level of these devices is from 85 to $100 \mathrm{~dB}(\mathrm{~A})$.

\section{Adaptive re-use for offices}

The development boom, which takes place in Wrocław in the last 20 years, similar to the one century before, caused that today there are 120 modern office buildings provided, with a total area of $1,000,000 \mathrm{~m}^{2}$, where over 50,000 employees are employed. About $20 \%$ of office space in Wroclaw is in refurbished historic buildings. In all these buildings, rapidly growing Polish or international corporations operating in the sectors of Shared Services Centers (SSC), Business Process Outsourcing (BPO), IT centers and R\&D centers are located [22, 23]. The buildings built for them must not only meet basic legal requirements, but also have a unique architecture and meet all international recommendations: BOMA International, Rolfe Judd Architecture and CB Richard Ellis, as well as obtain internationally recognized certificates: LEED, BREEAM or DGNB [24]. Due to meeting the latest requirements, Wrocław office buildings are rented by such companies as: Hewlett-Packard, Google, IBM, Netia, Nokia, Parker Hannifin, Volvo, Toyota, Luxoft, Opera, Quatar Airways, Ryanair, Credit Suisse, Capgemini, Deloitte, Mellon Bank. When it comes to rank and attractiveness as a business centre, Wrocław is being equated with cities such as: Prague, Budapest, Barcelona or Dublin [2].

Optimization of the office space structure of office buildings involves creation of a representative entrance zone and an ideal working environment on (repeatable) office floors. At the same time, due to the prestigious locations of such facilities on the main streets and squares, it is common to provide commercial space in them, primarily on the Ground Floor. Thanks to this, they become attractive to the public and are an important factor building the city's urban atmosphere. The most serious limitation for the office buildings emerging in the centre is usually the lack of possibility to provide parking for building employees within the building (basements are not suitable), but it does not discourage international corporations (e.g. Norwegian Opera Software having its offices in Hieronimus I Office Building) to rent these spaces. Compensation is efficient public transport and a dense network of stops allowing access to any building within 5 minutes. Parking and Change Rooms for cyclists are created in the facilities. Municipal systems for renting bicycles and electric scooters are also very efficient.

The best examples of refurbished and efficiently operating as offices historic buildings (including retail on the Ground Floor) are: Municipal Offices at Nowy Targ 8 (former Oberpräsidium der Provinz Schlesien, built in 1914-1918, arch. Karl Löwe) and Municipal Offices at Zapolska Street 4 (former Allianz-Haus, 2010 arch Alvin Wedemann), New Point Offices at Ruska 11/12 Street and Białoskórnicza Street (former Geschäftshaus Max Goldstein Reussenhof, built in 1907, in accordance with the design by arch. Georg Mohr, refirbished and extended in 2005-2009 in accordance with the design by POINT Co. Ltd Pracownia Projektowa Sp. z o.o.), Business Centre Save The World at Oławska 12/13 Street and Łaciarska 3 Street (former Warenhaus Stefan Esders, built in 1902 in accordance with the design by Alvin Wedemann, refurbished in 2012-2014 in accordance with the design by Piotr Szarejko PAPS), Quantum Oławska Office Building at Oławska 10/11 Street (former Kaufhaus C\&A Brenninkmeijer, built in 1931 in accordance with the design by Seep Kaiser, refurbished in 2011-2012 in accordance with the design by Quantum Project sp. z o.o.) or Hieronimus I Office Building (known also as a 'glass house') at Świdnicka 34 Street and Teatralny 8 Square (former Geschäftshaus Julius Schottländer, built in 1911 in accordance with the design by Richard Ehrlich \& Paul Ehrlich, in 2011 allocated for office development, but finally refurbished in 2015 for an office building in accordance with the design by Grupa 33_03 [8]) and Pokoyhof Passage at Św. Antoniego Street 2/4 (former Geschäftshaus Pokoyhof, built in 1911, arch. Max Mathis, in 2007-2015 refurbished by Verity Development and Aim Engineering).

The form of adaptation of a historic office building for a modern office building is influenced by, sometimes contradictory, the original functional layout of the building (most often passage interior layout) and applicable office building design standards (open space and hot-desk layouts are expected, as well as reduced number of individual rooms). In the case of offices located in the former grand office buildings, the largest refurbishment 
works take place on the Ground Floor, in areas intended to receive customers. At the great expense, operating rooms or large retail areas, which must be fully accessible for disabled people, are being provided there. The cubicle office layout remains unchanged on the upper floors. In practice, this means that former office buildings should retain their original use, otherwise the scale of refurbishment will lead to the destruction of the majority of the original building substance.

This is due to the fact that in the case of commercial office buildings, the basic goal is always to achieve maximum efficiency of space use as well as the ability to meet variable requirements of tenants. For this reason, old commercial buildings with repetitive open plan floors, having skeletal post-beam structures with large spans, are much better suitable for modern offices (an example of the adaptation of the former Geschäftshaus Julius Schottlände to the Hieronimus I Office Building [8] (Fig. 18-21)). Retail buildings also meet without any problems the key requirements regarding the quality of office space. This applies to the fire resistance of the structure and its load carrying capacity of at least $3 \mathrm{KN} / \mathrm{m}^{2}\left(5 \mathrm{kN} / \mathrm{m}^{2}\right.$ for escape routes). Due to the specifics of the use, the minimum clear height of office space should not be less than $2.70 \mathrm{~m}$ [21]. In historic buildings, even after the construction of raised floors and suspended ceilings housing the services, floors can easily reach clear height of $3.30 \mathrm{~m}$. With large windows existing in these buildings, it is possible to obtain the recommended level of daylight of 500 lux, for at least $70 \%$ of the leasable floor area.

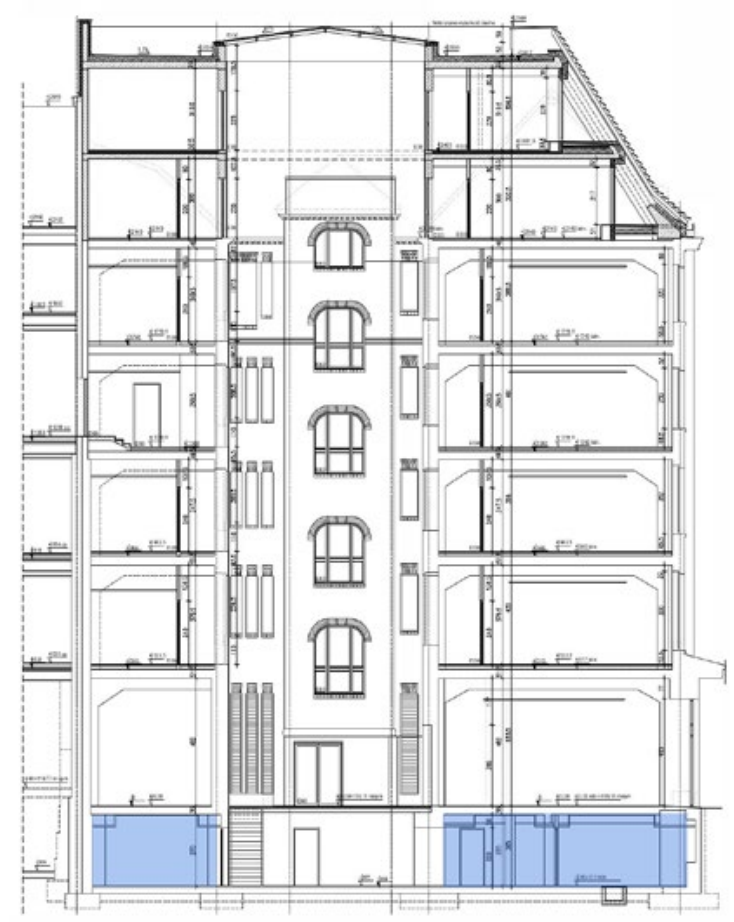

Fig. 18. Feniks Department Store refurbished in accordance with the design of Kirschke Pracownia Projektowa (1997-2015) - view from Świdnicka Street (photo by P. Kirschke).

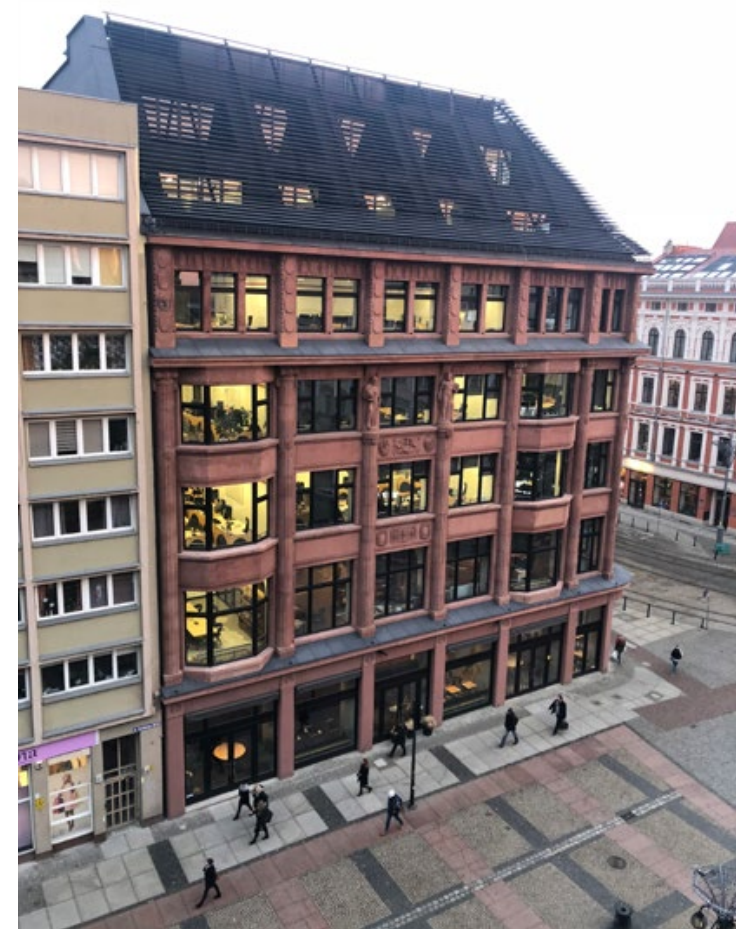

Fig. 19. Close-up look at the facade of Feniks Department Store building refurbished in accordance with the design of Kirschke Pracownia Projektowa (photo by P. Kirschke).

Obtaining required coefficients of space use efficiency becomes more difficult, as modern technical standards enforce the designation of much larger areas in an office building on the so-called core containing elements of vertical communication (stairs and lifts), toilets, as well as necessary spaces for air conditioning, ventilation, plumbing, electricity, telecommunication (including server rooms) plant rooms. Obtaining additional space becomes possible, by adapting the attic (additional office space (Fig. 18-19)) or deepened basements (usually used for meeting rooms) for new functions, adding new storeys without changing the building's volume (replacing floor slabs and decreasing the usable floor height) or adapting neighbouring buildings for the offices (example of a school building located in Wrocław, Teatralny Square 6-7, adjacent to the Hieronimus I building 
and creating a mini-office complex [8]). It rarely takes the form of supplements with ahistorical features in the form of extension (e.g. by changing old service yards to the patio or a multi-level atrium (Fig. 20) - this solution additionally contributes to the improvement of the interior microclimate), or the increasing height of the original building (additional volume is obtained by changing the geometry of the original roof or takes the form of extensive dormers), the use of which requires high design craftsmanship and respect for the cultural environment in the relation between the old and the new.

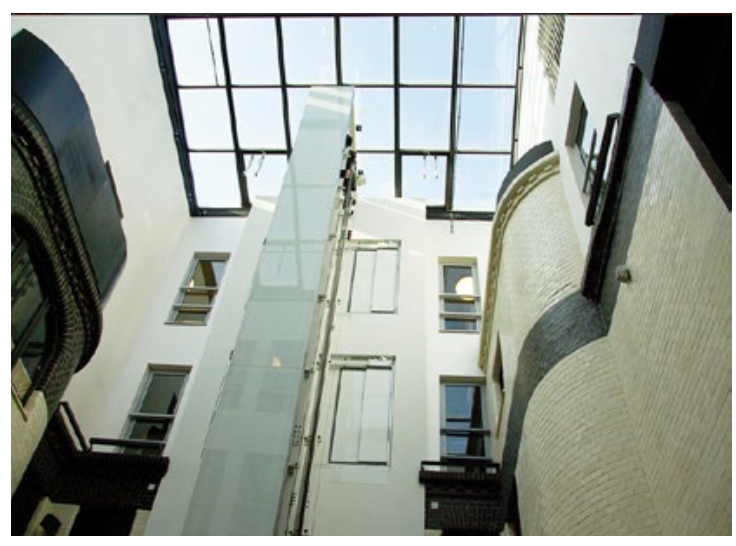

Fig. 20. The multi-story atrium of Hieronimus I Office Building refurbished in accordance with the design by Grupa 33_03 - a view showing the new glazed elevator shaft (photo by Grupa 33_03).

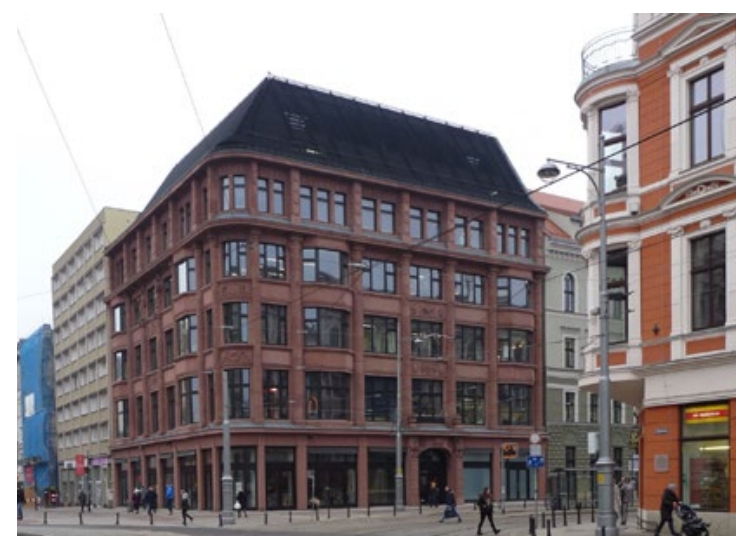

Fig. 21. Hieronimus I Office Building refurbished in 2015 in accordance with the design by Grupa 33_03 - view from the South (photo by P. Kirschke).

Another element characteristic for the buildings constructed at the turn of the $19^{\text {th }}$ and $20^{\text {th }}$ centuries which are in contradiction to the contemporary standards of office building design are irrationally large and open stairwells with stairs of steel or wooden structure (often quarter-turn stairs) that are exposed to smoke during a fire and can not in this shape serve as an escape route. Nevertheless, they have a unique historic value and are protected, therefore, in order to use them for evacuation in the course of the design (including CFD simulation) and consultations with the fire expert solutions are being developed to compensate for incompatibilities in fire protection in relation to the Regulations, e.g. total or partial (at the top) separation of staircases in the form of fire curtains, protection of the stairwell by providing overpressure relevant to a given class, construction of a DSO warning system in the building, application of the SAP fire alarm system, and subdivision of the building into small fire zones.

Flexible and easy to maintain horizontal distribution of the services is possible due to raised floors provided on existing floor slabs, as well as suspended ceilings. In the case of rooms with decorative vaults (basements) ventilation ducts are placed in their groins, and also distributed outside the outline of the historic building (e.g. in the basement of the courtyard changed to the atrium or in the newly built wings of the complex). However, extensive service ducts are located near vertical communication, sometimes also in place of demolished service staircases (as in the case of Hieronimus I [8]). When planning the service routes within the heritage building, safe technologies are recommended, e.g. in the form of dry wall (instead of chasing and plastering), which will not only facilitate the maintenance of services in the future, but will limit the chasing and irreversible depletion of the historic substance [25].

Presented examples of adaptation of historic buildings to offices again prove that with the application of appropriate design strategies, provision of rooms adequate for office work with favourable coefficients, as well as energy efficiency is possible. Possible restrictions in this respect are compensated by the unique values of the building and excellent locations on the main streets, which increase the prestige of its Landlord. 


\section{Adaptive re-use for hotels}

Contemporary hotels created as a result of the secondary or purposeful adaptation of a historic building are one of the hallmarks of the hotel industry in the centers of Polish cities. As a result of this trend, the interest of prestigious hotel brands in such facilities increases, as well as there are increased tourist offers promoting areas and places where historic hotels are located [26]. The provision of hotel services in historic buildings is also regulated in Poland in formal and legal terms - in accordance with § 3 Point 1 of the Regulation of the Minister of Economy and Labour of 19 August 2004 on hotel facilities and other facilities where hotel services are provided (Journal of Laws of 2017, item 2166) [27]: it is allowed to deviate as to the equipment and scope of services provided in hotel facilities [...] listed [...] or list of architectural and construction monuments and objects whose historical character is obvious. In connection with the above, in every case of adapting a historic object to a hotel, the goal should be, among others, underlining and use of original artistic values and incorporation into a new utility function, thanks to which the unique value of such development, and in practice also its tourist popularity, will increase.

There are numerous historic hotels preserved in Wrocław, most of which have been refurbished in the last decade to meet contemporary hotel standards. Examples of these are hotels located at Piłsudskiego Street: Hotel Polonia (former Hotel Vier Jahreszeiten built in 1906-1911, arch. Paul Rother, in 2007-2014 refurbished in accordance with the design by Rafin Sp. z o.o.), Piast Hotel (former Kronprinz Hotel built in 1908, arch. Waldemar Wildbradt, in 2014 refurbished in accordance with the design by Kwolek \& Januszkiewicz) and Grand Hotel (former Hôtel du Nord, built in 1904, arch. Paul Rother, in 2017-2019 refurbished in accordance with the design by GREG). Beside them the analysis concerned also: five star Monopol Hotel at H. Modrzejewskiej 2 Street (built in 1891 - 1892 in accordance with the design by Karl Grosser; west wing of the building was used for the hotel, while the east section was housing Kaufhaus Rudolf Mosse Department Store, in 2007-2009 refurbished in accordance with the design by Biuro Projektów i Ekspertyz ARCHIKON [9, 28] (Fig. 22-24)), four-star hotel AC by Marriott at Plac Wolności 10 (built in 1876, Reichsbank the first palace bank in Wrocław, in accordance with the design by Johanns Eduards Jacobstahls and Schlesische Immobilien AG - architect Friedrich Barchewitz, initially planned for a retail and residential function, in 2016-2017 adapted for a hotel in accordance with the design by MTA Tomasz Marhall [10]), four-star Grand City Hotel Wroclaw at Ruska 7 St. and Rzeźnicza 1 Street (former Geschäftshaus Adolf Kreutzberger, built in 1913 by arch Alvin Wedemann, firstly refurbished in 1993-1995 to the branch of Bank Handlowy in Warsaw SA, then in 2016-2018 to the Hotel according to the design by Archicom Studio Sp. z o.o.) and Hotel "Pod Złotą Koroną" at Rynek 29 and Oławska 2 St. (former Geschäftshaus zur Goldenen Krone, built in 1904 in accordance with the design by Heinrich Joseph Kayser \& Karl von Großheim, refurbished firstly into an office building in 1959 to the design by Zbigniew Politowski, then rebuilt in 2015-2019 for a hotel designed by Kirschke Pracownia Projektowa, Feniks Studio [7]).

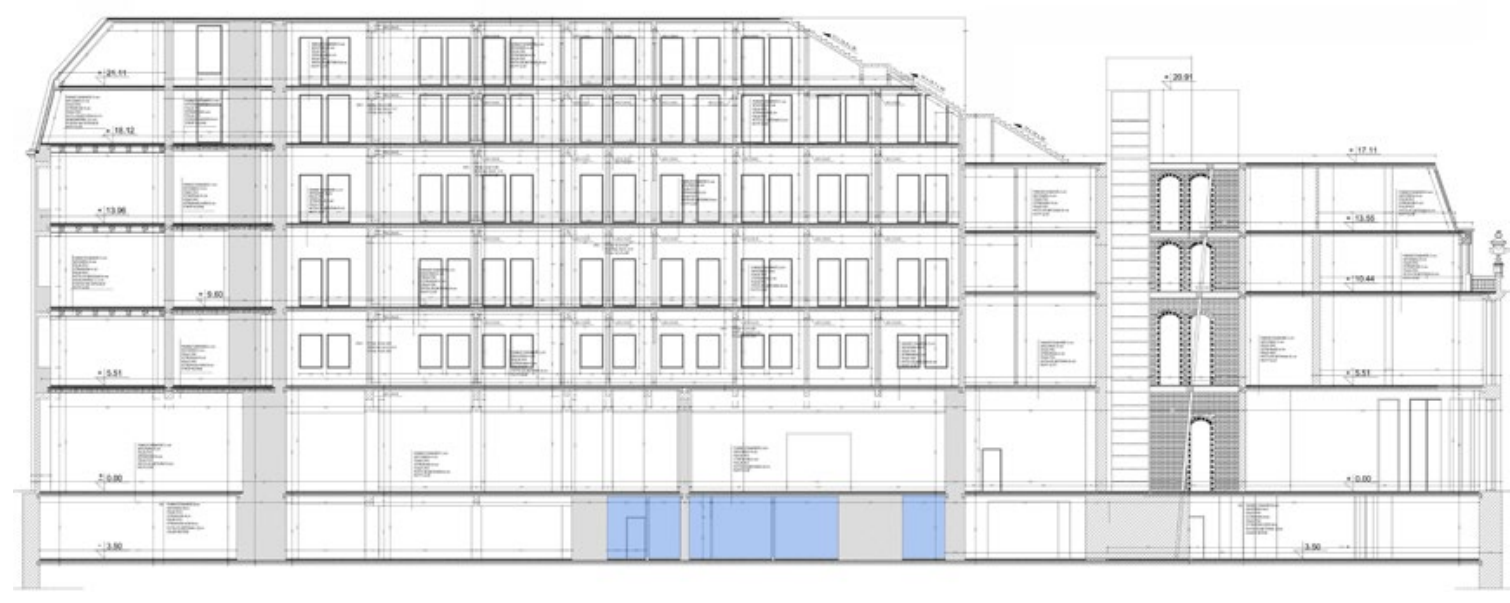

Fig. 22. Hotel Monopol Wrocław refurbished in 2007-2009 - section drawing with plant rooms indicated with light blue color (by Biuro Projektów i Ekspertyz ARCHIKON). 


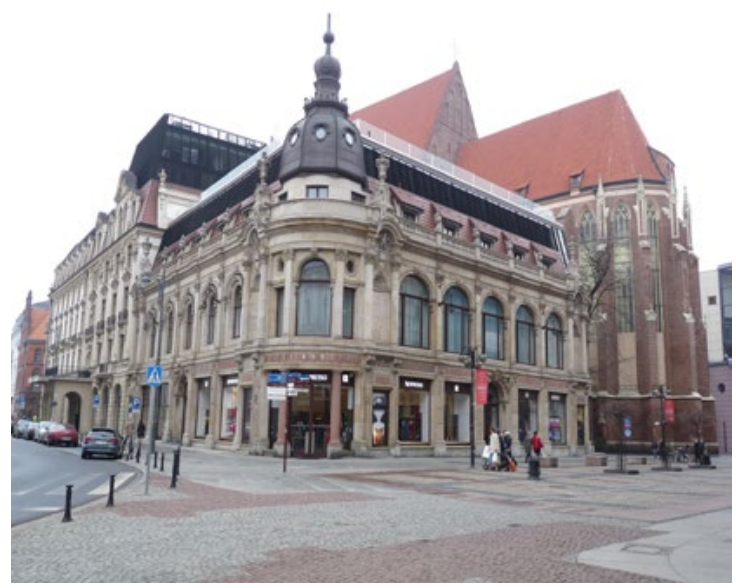

Fig. 23. Hotel Monopol Wrocław refurbished in 2007-2009 in accordance with the design by Biuro Projektów i Ekspertyz ARCHIKON - view from Świdnicka Street (photo by P. Kirschke).

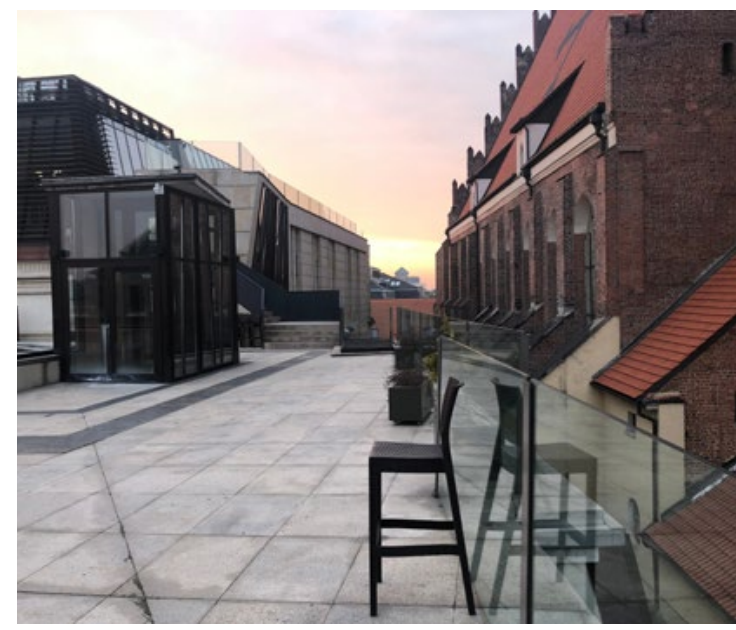

Fig. 24. Hotel Monopol Wrocław refurbished in 2007-2009 - view of the multifunctional terrace deck (photo by $\mathrm{E}$. Komarzyńska-Świeściak).

In order to present solutions and design strategies regarding cases of adaptive reuse of old commercial buildings or banks to hotels, the following examples were selected for analysis: hotels located at Piłsudskiego Street: Hotel Polonia (former Hotel Vier Jahreszeiten built in 1906-1911, arch. Paul Rother, in 2007-2014 refurbished in accordance with the design by Rafin Sp. z o.o.), Piast Hotel (former Kronprinz Hotel built in 1908, arch. Waldemar Wildbradt, in 2014 refurbished in accordance with the design by Kwolek \& Januszkiewicz) and Grand Hotel (former Hôtel du Nord, built in 1904, arch. Paul Rother, in 2017-2019 refurbished in accordance with the design by GREG).

Adaptation of a historic building to a hotel requires taking into account the specifics of the program and the function as well as space model of a hotel facility. Their essence is the existence of two structural operation units, which consist of four divisions: residential, catering, multifunctional and recreational rooms, and the back-up facilities: administration, staff facilities and technical. In modern refurbishment of hotel facilities, the challenge for the design team is usually to increase the usable area within the operational unit while meeting all the requirements of the Municipal Conservation Officer. Compared to historic buildings, modern hotels have a different structure of the residential section (standard and number of rooms), a more varied selection of restaurant options (apart from the main hotel restaurant there are, for example, coffee shops, bars, wine bars and multi-functional banquet rooms, not only within the building, but also on its terrace), and can also offer work spaces (meeting and conference rooms, mini-office centers for hotel guests) or recreation (swimming pool, SPA, fitness rooms). Increasing the operating area of the building adapted for the hotel while limiting the interference in the integrity of the heritage building is possible by applying similar solutions as in the previously discussed office buildings, i.e. by adapting the attic or basements, replacing floor slabs and reducing the usable floor height, extension or increasing the height, as well as adaptation neighbouring buildings for a hotel use (e.g. transforming a retail building and roofs of Monopol into a wing containing hotel services [9] Fig. 22, 24).

An additional challenge is the requirement to shape all function rooms in a historic building, usually determined not only by the type and category of the hotel, but also the standard of building equipment and finishing assigned to specific unique brands (e.g. the Marriott hotel network currently has 30 brands that have been tailored to the needs of a specific target group).

An important conditioning for the correct structure and program of the hotel building is the proper development of its surroundings, primarily the hotel's entrance area. It should not only be devoid of architectural barriers and guarantee high capacity, but also provide comfort, e.g. by providing a covered entrance to the building in the immediate vicinity of taxi and coach access. A most popular solution of the entrance area to the hotel in the form of revolving doors is in contradiction to the historic character of the heritage building, which is why the most common solutions in this case are original wooden sliding doors combined with efficient air curtains (Monopol Hotel [9]), or sliding glass doors (AC by Marriott [10]) creating a spacious vestibule. 
Examples of adaptation of historic buildings for the offices prove that using relevant design strategies, it is possible to achieve workspace with favourable coefficients of space use as well as energy efficiency. Possible restrictions in this respect are compensated by the unique values of the buildings and excellent location on the main streets, which raises the prestige of its Landlord. Thanks to the preserved historic architecture: façade details and unique elements of interior design, a historic building subjected to refurbishment can be an attraction, and even fulfill a didactic role, where the fact and effect of the exemplary adaptation becomes the special distinguishing feature. All the more so because the material testimonies of past era can perfectly coexist with contemporary architecture

\section{Conclusions}

Improvement of the image of Poland after joining the European Union, and particularly high position of Wrocław, which, apart from Warsaw and Krakow is perceived as the best place for commercial investments, and in connection with global crisis that limits places where you can safely and cheaply invest in large commercial buildings, hotels or corporate offices opens up more and more possibilities for this type of developments [22, 23]. Strengths of Wroclaw are: stable political and economic situation of Poland, good living conditions and safety, attractive environment (town planning and architecture), excellent service network, easy to find well-educated (office) staff, as well as efficient infrastructure, including: good train links, highway and modern airport. The examples of refurbishment of historic buildings and their adaptation for commercial, office and hotel use described in the paper have shown excellent effects of the revitalization of the entire historic area. In Wrocław, this was done in conjunction with the construction of a hundred multifunctional commercial facilities in this area. In total, together with the refurbishment of several dozen historic buildings, it had a very positive impact on the spatial order of the main squares and streets of the centre of Wrocław. It filled almost all existing gaps between the buildings since World War II. Thanks to the program and the rank of architecture, the city centre regained its former big city character.

The examples of developments in the Old Town in Wroclaw selected from a number of other developments, allowed to find out what problems the designer is faced with, while dealing with the adaptive reuse of commercial public facilities aimed not only at preserving the authenticity of a given monument, but also at ensuring safety and comfort for new users. They also prove that the adaptation of historic buildings to the requirements of modern use should be considered as one of the forms of protection and refurbishment of the architectural monument.

The most justified conclusion - resulting from the presented examples - is the need for consistent cooperation between various specialists at each stage of the development which is the refurbishment of a commercial building (selection of a user program, concept design, refurbishment design, Building Permit design and detail design, implementation). This should be prepared by an interdisciplinary design team coordinated by the architect-conservation officer, through the use of the Research by Design method [11, 12]. Properly executed pre-design works (archaeological research, iconographic and historical studies, conservation studies, stratigraphic research, surveys, especially based on 3D laser scanning of the building, recognition and review of previously proposed technical solutions) guarantee the success of the development and reduce the risk of losing the monument's authenticity, but also they are the basis for the sensibility and efficiency of the entire project. The key to the success of the project is a perfectly executed multi-disciplinary BP design, which is a formal and technical base for implementation. Finally, it is necessary to control the construction process, during which, due to discoveries, design decisions are often re-evaluated. The described examples of refurbishment of historic buildings in Wrocław and their adaptation to commercial, office or hotel use have shown how big (development) potential there is in buildings created at the turn of the $19^{\text {th }}$ and $20^{\text {th }}$ centuries. Their structural systems, space planning and technical solutions mean that with a properly selected user program, big interference in the historical substance is not necessary. It also reduces the costs that have to be borne to bring the buildings up to today's operational and safety requirements. The flexibility and adaptability to meet new requirements can be demonstrated by the various functional scenarios presented, which have been proposed in the form of multi-disciplinary BP designs, successfully implemented in Wrocław over the last twenty years. 
On the other hand, the examples of refurbishment of historic buildings and their adaptation for commercial, office or hotel use, described in this paper, showed a huge development potential of buildings from the turn of the $19^{\text {th }}$ and $20^{\text {th }}$ centuries. As mentioned in the paper, their structural systems, functional and technical solutions in many cases do not require large interference and financial expenditure to meet modern requirements for this type of buildings. The various scenarios proposed in the form of multi-disciplinary projetcs for buildings presented in the article over the last years prove that they are flexible in adapting them for various needs and the limited scope of necessary restoration and adaptation works.

\section{References}

[1] Kirschke P (2015) Revaluation of Wroclaw public use buildings in years 2005-2013. Civil and Environmental Engineering Reports, vol. 18, nr 3, pp. 75-83. https://doi.org/10.1515/ceer-2015-0038

[2] European Best Destinations (2018) Best places to travel in Europe 2018. European Best Destinations. https://www.europeanbestdestinations.com/european-best-destinations-2018/. Accessed 14 February 2018

[3] Kirschke K (2005) Fasady wrocławskich obiektów komercyjnych z lat 1890-1930. Struktura. Kolorystyka. [Facades of commercial buildings in Wroclaw in the years 1890-1930. Structure - colour scheme - decoration], Wrocław, Oficyna Wydaw. Politechniki Wrocławskiej.

[4] Maćków Pracownia Projektowa (2006) Renovation, reconstruction and extension project of DTC "Renoma" Department Store Building at Świdnicka Street 40 in Wrocław [Building Permit Documentation].

[5] Kirschke Pracownia Projektowa (2010) Renovation and reconstruction project of PSS „Feniks" Department Store at Szewska Street 75/77, Kurzy Targ and Rynek 31/32 in Wroctaw [Building Permit Documentation].

[6] Kirschke Pracownia Projektowa (2012) Renovation and reconstruction project of the building in Rynek 50 in Wrocław [Building Permit Documentation].

[7] Kirschke Pracownia Projektowa (2014) Reconstruction and adaptive reuse project of the office commercial building „Pod Złota Koronq" to a hotel at Rynek 29 and Oławska Street 2 in Wrocław [Building Permit Documentation].

[8] Grupa 33_03. Anita Luniak_Teresa Mromlińska (2014) Reconstruction and extension project of the office commercial buildings at Świdnicka Street 34 / Plac Teatralny 6- and 8, in Wrocław [Building Permit Documentation].

[9] Biuro Projektów i Ekspertyz ARCHIKON (2007) Adaptive reuse, reconstruction and extension project of "Monopol Wrocław Hotel" at Modrzejewska Street 2 [Building Permit Documentation].

[10] MTA Tomasz Marhall (2016) Reconstruction project of the residential and commercial building at Plac Wolności 10 in Wrocław [Building Permit Documentation].

[11] Hauberg J (2011) Research by Design - a research strategy, AE... Revista Lusófona de Architectura e Educacao, no. 5, pp. 46-56.

[12] Sequeira João M (2012) Architecture \& Research: a possible structure. Lusofona Journal of Architecture and Education, [S.I.], n. 5, pp. 135-151.

[13] Janowski Z, Janowski M (2009) Problemy projektowe związane z adaptacją budynków zabytkowych na cele użyteczności publicznej [Design problems with the adaptation of historical buildings to the aim of the public use]. Czasopismo Techniczne. Budownictwo, Wydawnictwo Politechniki Krakowskiej im. Tadeusza Kościuszki, R. 106, z. 2-B, pp. 139-150.

[14] Handbuch der Architektur IV. Theil: Entwerfen, Anlage und Einrichtung der Gebäude 2. Halbband, 2. Heft: Carl Zaar, August Leo Zaar: Geschäfts- und Kaufhäuser, Warenhäuser und Messpaläste, Passagen oder Galerien. Paul Kick: Gebäude für Banken und andere Geldinstitute. Hans Auer: Börsengebäude. Stuttgart 1902). 2. Auflage: Alphons Schneegans: Geschäfts- und Kaufhäuser, Warenhäuser und Messpaläste, Passagen und Galerien, Grosshandelshäuser, Kontorhäuser, Börsengebäude. Paul Kick: Gebäude für Banken und andere Geldinstitute. Leipzig 1923.

[15] Pevsner N (1979) A History of Building Types, Princeton, Princeton University Press.

[16] Kirschke K (2015) Tenement house "Under the Golden Crown" in Wroclaw - renovation of the peculiar monument. Civil and Environmental Engineering Reports. vol. 19, no 4, pp. 51-59.

[17] Kirschke K, Kirschke P (2008) Restoration Strategies for a Commercial Facility: Facade of Centrum-Renoma Department Store in Wroclaw. The Journal Architecture Civil Engineering Environment ACEE, 2008 vol. 1, no. 3, pp. 11-20.

[18] Kirschke K, Kirschke P (2013) Wartościowanie w decyzjach architektonicznych na przykładzie rewitalizacji Wroclawskich obiektów użyteczności publicznej [Valuation in Architectural Decisions on the Basis of Refurbishment of Public Buildings 
in Wroclaw. Valuation of Listed Buildings]. In: Szmygin B (ed) Wartościowanie zabytków architektury, Warszawa, Polski Komitet Narodowy Międzynarodowej.

[19] Kirschke P (2014) Wrocławskie zabytkowe obiekty komercyjne, których funkcja przestała się sprawdzać, W: Wartość funkcji w obiektach zabytkowych [Listed Commercial Buildings in Wroclaw no Longer Functional. Importance of Function in Listed Buildings]. In: Szmygin B (ed) Polski Komitet Narodowy ICOMOS Warszawa, pp. 137-154.

[20] Act of 23 July 2003 on On The Protection Of Monuments And The Care Of Historical Monuments (Journal of Laws of the Republic of Poland of 2003 nr 162, Pos. 1568).

[21] Regulation Of The Minister Of Infrastructure Of 12 April 2002 On Technical Conditions, Which Should Correspond To The Buildings And Their Location (Journal of Laws of the Republic of Poland of $2002 \mathrm{nr} 75$, Pos. 690).

[22] Kollewe J (2011) Wroclaw transformed. The Guardian. https://www.theguardian.com/world/2011/apr/06/new-europe-poland. Accessed 14 February 2018

[23] Gowans G (2017) Financial Times award Wroclaw Poland's FDI Strategy prize. Wroclaw Uncut. http://wroclawuncut. com/2017/02/24/wroclaw-handed-polands-fdi-financial-times-prize/. Accessed 14 February 2018.

[24] Nag P K (2019) Office Buildings Health, Safety and Environment, Singapor, Springer Nature Singapore Pte Ltd, pp. 445-463.

[25] Lewicka M L (2009) Nieinwazyjna metoda modernizacji i aranżacji wnętrz w budowlach zabytkowych [Non-invasive method of refurbishment and interior design in historic buildings]. In: Szmygin B (ed) Adaptacja obiektów zabytkowych do współczesnych funkcji użytkowych, Lubelskie Towarzystwo Naukowe, Międzynarodowa rada ochrony Zabytków ICOMOS, Politechnika Lubelska, Warszawa-Lublin, pp. 55-68.

[26] Grabiszewski M (2009) Adaptacja budowli zabytkowych na cele hotelowe [Adaptive reuse of historic buildings to new hotels]. In: Szmygin B (ed) Adaptacja obiektów zabytkowych do współczesnych funkcji użytkowych, Lubelskie Towarzystwo Naukowe, Międzynarodowa rada ochrony Zabytków ICOMOS, Politechnika Lubelska, Warszawa-Lublin, pp. 43-53.

[27] Regulation of the Minister of Economy and Labour of 19 August 2004 on hotel facilities and other facilities where hotel services are provided (Journal of Laws of the Republic of Poland of 2017, Pos. 2166.)

[28] Ostrowska M, Ziental K (2010) Dom handlowy i hotel Monopol we Wrocławiu. Tradycja a nowoczesność [Monopol department store and hotel in Wrocław. Tradition and modernity]. Archivolta, 2(46)/2010, pp. 95-98.

\title{
Przebudowy komercyjnych obiektów użyteczności publicznej na Starym Mieście we Wrocławiu. Bezpieczeństwo i komfort użytkowania a zachowanie autentyczności zabytku
}

\begin{abstract}
Streszczenie: $W$ centrum Wrocławia istnieje ponad sto zabytkowych obiektów użyteczności publicznej przystosowanych do pełnienia komercyjnych funkcji usługowych. Na tle dzisiejszych kosmopolitycznych galerii i biurowców gmachy te wyróżniają się stylową architekturą, utrzymaną w formach eklektycznych, secesyjnych lub modernistycznych. W procesie ich rewaloryzacji istnieje potrzeba pogodzenia konieczności maksymalnej ochrony historycznej substancji z komfortem i bezpieczeństwem użytkowania. Wielobranżowy projekt budowlany stanowiący podstawę przebudowy zabytku musi być poprzedzony analizami konserwatorskimi oraz koncepcjami symulującymi możliwe warianty programowe. Pozwala to na powiązanie oceny wartości architektury z dobraniem funkcji adekwatnej do lokalizacji i historycznej struktury obiektu. Dalszy wieloetapowy proces projektowy i realizacja takiego przedsięwzięcia powinny opierać się o schemat Research by Design. Pozwala to na kontrolowanie przebiegu inwestycji i zastosowanie takich rozwiązań przestrzennych i technicznych, które ograniczają destrukcję jego historycznej substancji. W referacie przedstawiono wnioski z kilkunastu tak przeprowadzonych przedsięwzięć, podczas których w zabytkach udało się stworzyć wysokiej klasy domy handlowe, banki, hotele lub prestiżowe biurowce. Istotą tych inwestycji było zachowanie autentyczności zabytku i wyeksponowanie jego walorów, przy zapewnieniu niezbędnych instalacji infrastrukturalnych i związanych z nimi pomieszczeń oraz urządzeń gwarantujących bezpieczeństw i komfort użytkowy.
\end{abstract}

Słowa kluczowe: rewaloryzacja, budynki komercyjne, konserwacja zabytków, Research by Design, rozwój zrównoważony, Wrocław 